Short Communication

\title{
Pseudomonads from wild free-living sea turtles in Príncipe Island, Gulf of Guinea
}

\author{
Manuela Oliveira ${ }^{\mathrm{a}}$, Isa Serrano ${ }^{\mathrm{a}, *}$, José Pedro Santos $^{\mathrm{a}}$, Florence Bilocq ${ }^{\mathrm{b}}$, Nuno Pereira ${ }^{\mathrm{c}}$, \\ Nuno de Santos Loureiro ${ }^{\mathrm{d}}$, Luis Tavares ${ }^{\mathrm{a}}$, Jean-Paul Pirnay ${ }^{\mathrm{b}}$, Daniel De Vos ${ }^{\mathrm{b}}$ \\ a Centre for Interdisciplinary Research in Animal Health, Faculty of Veterinary Medicine, University of Lisbon, Lisbon, Portugal \\ b Queen Astrid Military Hospital, Laboratory for Molecular and Cellular Technology, Brussels, Belgium \\ c Oceanário de Lisboa, Lisbon, Portugal \\ d Department of Earth, Sea and Environmental Sciences, Faculty of Sciences and Technology, University of Algarve, Faro, Portugal
}

\section{A R T I C L E I N F O}

\section{Keywords:}

Antibiotic resistance

Chelonia mydas

Eretmochelys imbricate

Príncipe Island

Pseudomonas aeruginosa

\begin{abstract}
A B S T R A C T
Dissemination of antibiotic resistance is a major concern, especially in aquatic environments, where pollution contributes for resistant bacteria selection. These strains may have serious health implications, especially for endangered species, including the sea turtles' hawksbill Eretmochelys imbricata and green turtles Chelonia mydas.

We aimed to evaluate the presence of antibiotic resistant pseudomonads in wild sea turtles from Príncipe Island, São Tomé and Príncipe, Guinea Gulf. Isolates were obtained from oral and cloacal swabs of free-living turtles by conventional techniques. Pseudomonads screening was performed by multiplex-PCR (oprI/oprL) and biochemical identification and antibiotic resistance profiling were achieved using Vitek2. All pseudomonad isolates were genotyped by Rep-PCR.

Thirteen isolates were oprI-positive and classified as pseudomonads, eight from the genus Pseudomonas with the species $P$. aeruginosa, $P$. stutzeri, and $P$. mendocina, and five co-isolated Alcaligenes faecalis. The $P$. aeruginosa isolate was also oprL-positive. Regarding isolates susceptibility profile, $38.5 \%$ were susceptible to all antibiotics tested, and multidrug resistant (MDR) strains were not identified. DNA fingerprinting did not show any specific clonal-cluster similarity.

Data on the worldwide incidence of antibiotic resistance among wildlife is still very scarce, especially concerning remote tropical areas. Since Pseudomonas genus has emerged as a group of increasingly reported opportunistic microorganisms in human and veterinary medicine with high resistance levels, it could be used as a tool for environmental resistance surveillance, particularly considering their ubiquity.
\end{abstract}

\section{Introduction}

West coast African countries are important regions as habitats for feeding and nesting of sea turtles, including hawksbills (Eretmochelys imbricata, Linnaeus, 1766) and green turtles (Chelonia mydas, Linnaeus, 1758) (Formia et al., 2003), two species respectively considered as critically endangered and as endangered, according to The IUCN Red List of Threatened Species (Camacho et al., 2013; González-Garza et al., 2015; Orós et al., 2005). Mortality causes include direct and indirect anthropogenic activities, such as fishing, trauma and pollution, but these animals can also be affected by neoplasia and infectious diseases, namely pneumonia, hepatitis, meningitis and septicemia (Óros et al., 2005).

Although presenting a high longevity, sea turtles are extremely vulnerable to organic and chemical pollution (Foti et al., 2009), which makes them good indicator species for environmental monitoring (AlBahry et al., 2009, 2012; Barbour et al., 2007; Foti et al., 2009), namely for evaluating the presence of potentially pathogenic and antibiotic resistant bacteria (Foti et al., 2009). The global dissemination of antibiotic resistance in the environment is a major global concern (Al-Bahry et al., 2009; Foti et al., 2009), especially in aquatic environments, since the presence of sewage, chemicals and other waste products among which antibiotic and pesticide residues may select for resistant bacteria (Al-Bahry et al., 2012; Foti et al., 2009; Kümmerer and Henninger, 2003; Kümmerer, 2004).

Among antibiotic resistant microbiota, special attention has been given to Pseudomonas spp., as multi-, extensive- and pan-resistant species and strains are constantly and increasingly emerging (McCarthy, 2015). Pseudomonads, including Pseudomonas aeruginosa, are ubiquitous Gram-negative bacteria, present in several ecological

\footnotetext{
* Correspondenc to: Animal Health Department, Faculty of Veterinary Medicine, Avenida da Universidade Técnica, 130-477 Lisbon, Portugal.

E-mail address: isaserrano@gmail.com (I. Serrano).
} 
Table 1

Antibiotic resistance profile of the 13 pseudomonads strains and Alcaligenes faecalis obtained from oral and cloacal swabs of free-living turtles of Príncipe Island.

\begin{tabular}{|c|c|c|c|c|c|c|c|c|c|c|c|c|c|c|c|}
\hline & & \multicolumn{13}{|c|}{ Antibiotic Class, MIC breakpoint $\mu \mathrm{g} / \mathrm{mL}$} & \\
\hline & & \multicolumn{3}{|c|}{ Penicillins } & \multicolumn{2}{|c|}{$\begin{array}{l}\text { Cepha } \\
\text { losporins }\end{array}$} & \multirow{2}{*}{ 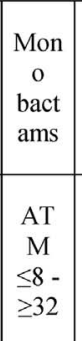 } & \multicolumn{2}{|c|}{$\begin{array}{c}\text { Carbapene } \\
\mathrm{ms}\end{array}$} & \multicolumn{3}{|c|}{$\begin{array}{c}\text { Amino } \\
\text { glycosides }\end{array}$} & \multirow{2}{*}{$\begin{array}{c}\begin{array}{c}\text { Fluo } \\
\text { ro } \\
\text { quin } \\
\text { olo } \\
\text { nes }\end{array} \\
\\
\text { CIP } \\
\leq 1- \\
\geq 4\end{array}$} & \multirow{2}{*}{$\begin{array}{c}\text { Poly } \\
\text { myx } \\
\text { in }\end{array}$} & \\
\hline $\begin{array}{c}\text { Strai } \\
\mathrm{n}\end{array}$ & $\begin{array}{c}\text { Spec } \\
\text { ie }\end{array}$ & $\begin{array}{c}\text { TIC } \\
\leq 64 \\
- \\
\geq 12 \\
8\end{array}$ & $\begin{array}{c}\text { TCC } \\
\leq 64 / \\
2- \\
\geq 12 \\
8 / 2\end{array}$ & $\begin{array}{c}\text { TZP } \\
\leq 16 / \\
4- \\
\geq 12 \\
8 / 4\end{array}$ & $\begin{array}{c}\mathrm{CA} \\
\mathrm{Z} \\
\leq 8- \\
\geq 32\end{array}$ & $\begin{array}{l}\text { FEP } \\
\leq 8- \\
\geq 32\end{array}$ & & $\begin{array}{l}\text { IPM } \\
\leq 4- \\
\geq 16\end{array}$ & $\begin{array}{c}\mathrm{ME} \\
\mathrm{M} \\
\leq 2- \\
\geq 8\end{array}$ & $\begin{array}{c}\text { AN } \\
\leq 16 \\
- \\
\geq 64\end{array}$ & $\begin{array}{l}\text { GM } \\
\leq 4- \\
\geq 16\end{array}$ & $\begin{array}{l}\text { TM } \\
\leq 4- \\
\geq 16\end{array}$ & & & $\begin{array}{c}\text { Resistance } \\
\text { profile }\end{array}$ \\
\hline $\begin{array}{l}\mathrm{T} 1- \\
5-\mathrm{O}\end{array}$ & $\begin{array}{c}P . \\
\text { stutz } \\
\text { eri }\end{array}$ & $\begin{array}{l}<=8 \\
/ \mathrm{S}\end{array}$ & $\begin{array}{l}<=8 \\
/ \mathrm{S}\end{array}$ & $\begin{array}{c}<=4 \\
/ S\end{array}$ & $\begin{array}{l}<=1 \\
/ S\end{array}$ & $\begin{array}{l}<=1 \\
/ S\end{array}$ & $\begin{array}{l}<=1 \\
/ S\end{array}$ & $\begin{array}{c}<=0 \\
25 / \\
\mathrm{S}\end{array}$ & $\begin{array}{c}<=0 . \\
25 / \\
\mathrm{S}\end{array}$ & $\begin{array}{l}<=2 \\
/ S\end{array}$ & $\begin{array}{l}<=1 \\
/ \mathrm{S}\end{array}$ & $\begin{array}{l}<=1 \\
/ S\end{array}$ & $\begin{array}{c}<=0 . \\
25 / \\
\mathrm{S}\end{array}$ & $\begin{array}{l}<=0 . \\
5 / S\end{array}$ & - \\
\hline $\begin{array}{c}\text { T1- } \\
15- \\
\text { C }\end{array}$ & $\begin{array}{c}\text { A. } \\
\text { faec } \\
\text { alis }\end{array}$ & $\begin{array}{c}>=1 \\
28 / \\
\mathrm{R}\end{array}$ & $\begin{array}{c}>=1 \\
28 / \\
R\end{array}$ & $\begin{array}{l}<=4 \\
/ S\end{array}$ & $4 / S$ & $\begin{array}{l}<=1 \\
/ S\end{array}$ & $\begin{array}{l}>=6 \\
4 / \mathrm{R}\end{array}$ & $\begin{array}{c}<=0, \\
25 / \\
\mathrm{S}\end{array}$ & $1 / \mathrm{S}$ & $\begin{array}{l}<=2 \\
/ S\end{array}$ & $\begin{array}{l}<=1 \\
/ S\end{array}$ & $\begin{array}{l}<=1 \\
/ S\end{array}$ & $\begin{array}{c}<=0 \\
25 / \\
\mathrm{S}\end{array}$ & $\begin{array}{l}<=0 . \\
5 / \mathrm{S}\end{array}$ & $\begin{array}{c}\text { TIC } \\
\text { TCC } \\
\text { ATM }\end{array}$ \\
\hline $\begin{array}{l}\mathrm{T} 2- \\
6-\mathrm{O}\end{array}$ & $\begin{array}{c}\text { A. } \\
\text { faec } \\
\text { alis }\end{array}$ & $\begin{array}{c}64 / \\
S\end{array}$ & $\begin{array}{c}64 / \\
\mathrm{S}\end{array}$ & $\begin{array}{l}<=4 \\
/ S\end{array}$ & $2 / S$ & $\begin{array}{l}<=1 \\
/ \mathrm{S}\end{array}$ & $\begin{array}{c}32 / \\
\mathrm{R}\end{array}$ & $\begin{array}{c}<=0 \\
25 / \\
\mathrm{S}\end{array}$ & $\begin{array}{c}0.5 / \\
\mathrm{S}\end{array}$ & $\begin{array}{l}<=2 \\
/ S\end{array}$ & $\begin{array}{l}<=1 \\
/ \mathrm{S}\end{array}$ & $\begin{array}{l}<=1 \\
/ \mathrm{S}\end{array}$ & $\begin{array}{c}<=0 \\
25 / \\
\mathrm{S}\end{array}$ & $\begin{array}{l}<=0 . \\
5 / S\end{array}$ & ATM \\
\hline $\begin{array}{l}\text { T2- } \\
10- \\
\text { C }\end{array}$ & $\begin{array}{c}P . \\
\text { stutz } \\
\text { eri }\end{array}$ & $\begin{array}{l}<=8 \\
/ \mathrm{S}\end{array}$ & $\begin{array}{l}<=8 \\
/ S\end{array}$ & $\begin{array}{l}<=4 \\
/ S\end{array}$ & $\begin{array}{l}<=1 \\
/ S\end{array}$ & $\begin{array}{l}<=1 \\
/ S\end{array}$ & $\begin{array}{l}<=1 \\
/ S\end{array}$ & $\begin{array}{c}<=0 \\
25 / \\
\mathrm{S}\end{array}$ & $\begin{array}{c}<=0 . \\
25 / \\
S\end{array}$ & $\begin{array}{l}<=2 \\
/ S\end{array}$ & $\begin{array}{l}<=1 \\
/ \mathrm{S}\end{array}$ & $\begin{array}{l}<=1 \\
/ S\end{array}$ & $\begin{array}{c}<=0 \\
25 / \\
\mathrm{S}\end{array}$ & $\begin{array}{l}<=0 . \\
5 / S\end{array}$ & - \\
\hline $\begin{array}{c}\text { T2- } \\
12- \\
\mathrm{C}\end{array}$ & $\begin{array}{c}P . \\
\text { aeru } \\
\text { gino } \\
\text { sa }\end{array}$ & $\begin{array}{c}16 / \\
S\end{array}$ & $\begin{array}{c}16 / \\
S\end{array}$ & $8 / \mathrm{S}$ & $\begin{array}{l}<=1 \\
/ S\end{array}$ & $\begin{array}{l}<=1 \\
/ \mathrm{S}\end{array}$ & $2 / \mathrm{S}$ & $1 / \mathrm{S}$ & $\begin{array}{c}<=0 . \\
25 / \\
\mathrm{S}\end{array}$ & $\begin{array}{l}<=2 \\
/ S\end{array}$ & $2 / \mathrm{s}$ & $\begin{array}{l}<=1 \\
/ S\end{array}$ & $\begin{array}{c}<=0 \\
25 / \\
\mathrm{S}\end{array}$ & $\begin{array}{l}<=0 . \\
5 / S\end{array}$ & - \\
\hline $\begin{array}{l}\text { T3- } \\
4-\mathrm{O}\end{array}$ & $\begin{array}{c}P . \\
\text { stutz } \\
\text { eri }\end{array}$ & $\begin{array}{l}<=8 \\
/ \mathrm{S}\end{array}$ & $\begin{array}{l}<=8 \\
/ \mathrm{S}\end{array}$ & $\begin{array}{c}<=4 \\
/ S\end{array}$ & $\begin{array}{l}<=1 \\
/ \mathrm{S}\end{array}$ & $\begin{array}{l}<=1 \\
/ \mathrm{S}\end{array}$ & $\begin{array}{l}<=1 \\
/ \mathrm{S}\end{array}$ & $\begin{array}{c}<=0 \\
25 / \\
\mathrm{S}\end{array}$ & $\begin{array}{c}<=0 . \\
25 / \\
\mathrm{S}\end{array}$ & $\begin{array}{l}<=2 \\
/ S\end{array}$ & $\begin{array}{l}<=1 \\
/ \mathrm{S}\end{array}$ & $\begin{array}{l}<=1 \\
/ \mathrm{S}\end{array}$ & $\begin{array}{c}<=0 \\
25 / \\
\mathrm{S}\end{array}$ & $\begin{array}{l}<=0 . \\
5 / S\end{array}$ & - \\
\hline $\begin{array}{c}\text { T3- } \\
12- \\
\text { C }\end{array}$ & $\begin{array}{c}\text { A. } \\
\text { faec } \\
\text { alis }\end{array}$ & $\begin{array}{c}32 / \\
S\end{array}$ & $\begin{array}{c}32 / \\
\mathrm{S}\end{array}$ & $\begin{array}{l}<=4 \\
/ S\end{array}$ & $\begin{array}{l}<=1 \\
/ S\end{array}$ & $\begin{array}{l}<=1 \\
/ S\end{array}$ & $\begin{array}{c}32 / \\
\mathrm{R}\end{array}$ & $\begin{array}{c}0.5 / \\
\mathrm{S}\end{array}$ & $\begin{array}{c}<=0 . \\
25 / \\
\mathrm{S}\end{array}$ & $\begin{array}{l}<=2 \\
/ S\end{array}$ & $\begin{array}{l}<=1 \\
/ \mathrm{S}\end{array}$ & $\begin{array}{l}<=1 \\
/ S\end{array}$ & $\begin{array}{c}<=0 \\
25 / \\
\mathrm{S}\end{array}$ & $\begin{array}{l}<=0 . \\
5 / S\end{array}$ & ATM \\
\hline $\begin{array}{c}\text { T3- } \\
13- \\
\text { C }\end{array}$ & $\begin{array}{c}P . \\
\text { stutz } \\
\text { eri }\end{array}$ & $\begin{array}{c}>=1 \\
28 / \\
\mathrm{R}\end{array}$ & $\begin{array}{c}>=1 \\
28 / \\
R\end{array}$ & $\begin{array}{l}<=4 \\
/ S\end{array}$ & $4 / \mathrm{S}$ & $\begin{array}{l}<=1 \\
/ S\end{array}$ & $\begin{array}{l}>=6 \\
4 / R\end{array}$ & $1 / \mathrm{S}$ & $1 / \mathrm{S}$ & $\begin{array}{l}<=2 \\
/ S\end{array}$ & $\begin{array}{l}<=1 \\
/ \mathrm{S}\end{array}$ & $\begin{array}{l}<=1 \\
/ S\end{array}$ & $\begin{array}{c}<=0 \\
25 / \\
\mathrm{S}\end{array}$ & $\begin{array}{l}<=0 . \\
5 / S\end{array}$ & $\begin{array}{c}\text { TIC } \\
\text { TCC } \\
\text { ATM }\end{array}$ \\
\hline $\begin{array}{l}\mathrm{T} 5- \\
8-\mathrm{O}\end{array}$ & $\begin{array}{c}P . \\
\text { men } \\
\text { doci } \\
\text { na }\end{array}$ & $\begin{array}{c}>=1 \\
28 / \\
\mathrm{R}\end{array}$ & $\begin{array}{c}64 / \\
S\end{array}$ & $\begin{array}{l}<=4 \\
/ S\end{array}$ & $4 / \mathrm{S}$ & $\begin{array}{l}<=1 \\
/ S\end{array}$ & \begin{tabular}{|l|}
$>=6$ \\
$4 / R$
\end{tabular} & $\begin{array}{c}<=0 \\
25 / \\
\mathrm{S}\end{array}$ & $\begin{array}{c}<=0 . \\
25 / \\
\mathrm{S}\end{array}$ & $\begin{array}{l}<=2 \\
/ S\end{array}$ & $\begin{array}{l}<=1 \\
/ \mathrm{S}\end{array}$ & $\begin{array}{l}<=1 \\
/ \mathrm{S}\end{array}$ & $\begin{array}{c}<=0 \\
25 / \\
\mathrm{S}\end{array}$ & $\begin{array}{l}<=0 . \\
5 / \mathrm{S}\end{array}$ & $\begin{array}{c}\text { TIC } \\
\text { ATM }\end{array}$ \\
\hline $\begin{array}{l}\mathrm{T} 7- \\
3-\mathrm{O}\end{array}$ & $\begin{array}{c}P . \\
\text { stutz } \\
\text { eri }\end{array}$ & $\begin{array}{c}>=1 \\
28 / \\
\mathrm{R}\end{array}$ & $\begin{array}{c}64 / \\
\mathrm{S}\end{array}$ & $\begin{array}{c}<=4 \\
/ S\end{array}$ & $2 / S$ & $\begin{array}{l}<=1 \\
/ \mathrm{S}\end{array}$ & \begin{tabular}{|l|}
$>=6$ \\
$4 / R$
\end{tabular} & $1 / \mathrm{S}$ & $\begin{array}{c}<=0 . \\
25 / \\
\mathrm{S}\end{array}$ & $\begin{array}{l}<=2 \\
/ S\end{array}$ & $\begin{array}{l}<=1 \\
/ \mathrm{S}\end{array}$ & $\begin{array}{l}<=1 \\
/ \mathrm{S}\end{array}$ & $\begin{array}{c}<=0 \\
25 / \\
\mathrm{S}\end{array}$ & $\begin{array}{l}<=0 . \\
5 / S\end{array}$ & $\begin{array}{c}\text { TIC } \\
\text { ATM }\end{array}$ \\
\hline $\begin{array}{l}\text { T9- } \\
5-\mathrm{O}\end{array}$ & $\begin{array}{c}\text { A. } \\
\text { faec } \\
\text { alis }\end{array}$ & $\begin{array}{c}64 / \\
S\end{array}$ & \begin{tabular}{|c|}
$32 /$ \\
$\mathrm{S}$
\end{tabular} & $8 / \mathrm{S}$ & $4 / S$ & $2 / \mathrm{S}$ & $\begin{array}{l}>-6 \\
4 / R\end{array}$ & $\begin{array}{c}<=0 \\
25 / \\
\mathrm{S}\end{array}$ & $\begin{array}{c}<=0 . \\
25 / \\
\mathrm{S}\end{array}$ & $\begin{array}{l}<=2 \\
/ S\end{array}$ & $\begin{array}{l}<=1 \\
/ \mathrm{S}\end{array}$ & $\begin{array}{l}<=1 \\
/ \mathrm{S}\end{array}$ & $\begin{array}{c}<=0 \\
25 / \\
\mathrm{S}\end{array}$ & $\begin{array}{l}<=0 . \\
5 / \mathrm{S}\end{array}$ & ATM \\
\hline $\begin{array}{l}\text { T9- } \\
6-\mathrm{O}\end{array}$ & $\begin{array}{c}\text { A. } \\
\text { faec } \\
\text { alis }\end{array}$ & $\begin{array}{c}32 / \\
\mathrm{S}\end{array}$ & $\begin{array}{c}32 / \\
\mathrm{S}\end{array}$ & $8 / \mathrm{S}$ & $4 / \mathrm{S}$ & $\begin{array}{l}<=1 \\
/ \mathrm{S}\end{array}$ & $\begin{array}{l}>=6 \\
4 / R\end{array}$ & $\begin{array}{c}<=0 \\
25 / \\
\mathrm{S}\end{array}$ & $\begin{array}{c}<=0 . \\
25 / \\
\mathrm{S}\end{array}$ & $\begin{array}{l}<=2 \\
/ S\end{array}$ & $\begin{array}{l}<=1 \\
/ \mathrm{S}\end{array}$ & $\begin{array}{c}<=1 \\
/ \mathrm{S}\end{array}$ & $\begin{array}{c}<=0 \\
25 / \\
\mathrm{S}\end{array}$ & $\begin{array}{l}<=0 . \\
5 / S\end{array}$ & ATM \\
\hline $\begin{array}{c}\mathrm{T} 12- \\
6-\mathrm{O}\end{array}$ & $\begin{array}{c}P . \\
\text { stutz } \\
\text { eri }\end{array}$ & $\begin{array}{l}<=8 \\
/ \mathrm{S}\end{array}$ & $\begin{array}{c}<=8 \\
/ S\end{array}$ & $\begin{array}{c}<=4 \\
/ S\end{array}$ & $\begin{array}{c}<=1 \\
/ S\end{array}$ & $\begin{array}{l}<=1 \\
/ S\end{array}$ & $\begin{array}{c}<=1 \\
/ S\end{array}$ & $\begin{array}{c}<=0 \\
25 / \\
\mathrm{S}\end{array}$ & $\begin{array}{c}<=0 . \\
25 / \\
\mathrm{S}\end{array}$ & $\begin{array}{l}<=2 \\
/ S\end{array}$ & $\begin{array}{l}<=1 \\
/ S\end{array}$ & $\begin{array}{c}<=1 \\
/ S\end{array}$ & $\begin{array}{c}<=0 \\
25\end{array}$ & $\begin{array}{l}<=0 . \\
5 / S\end{array}$ & - \\
\hline
\end{tabular}

O - oral; C - cloacae; Ticarcillin (TIC), ticarcillin + clavulanic acid (TCC), piperacillin + tazobactam (TZP), ceftazidime (CAZ), cefepime (FEP), aztreonam (ATM), imipenem (IPM), meropenem (MEM), amikacin (AN), gentamicin (GM), tobramycin (TM), ciprofloxacin (CIP), and colistin (CS); Resistant values are marked as grey.

environments, such as water, soil and rhizosphere (Pirnay et al., 2002; Pirnay et al., 2005). Besides being recognized as important human opportunistic pathogens responsible for nosocomial infections (Oliver et al., 2015), they are also associated with important animal-related infections, affecting production and companion animals as well as wildlife (Haenni et al., 2015).

The occurrence of antibiotic resistant Pseudomonas (Al-Bahry et al., 2009; Barbour et al., 2007; Díaz et al., 2006; Foti et al., 2009) and 


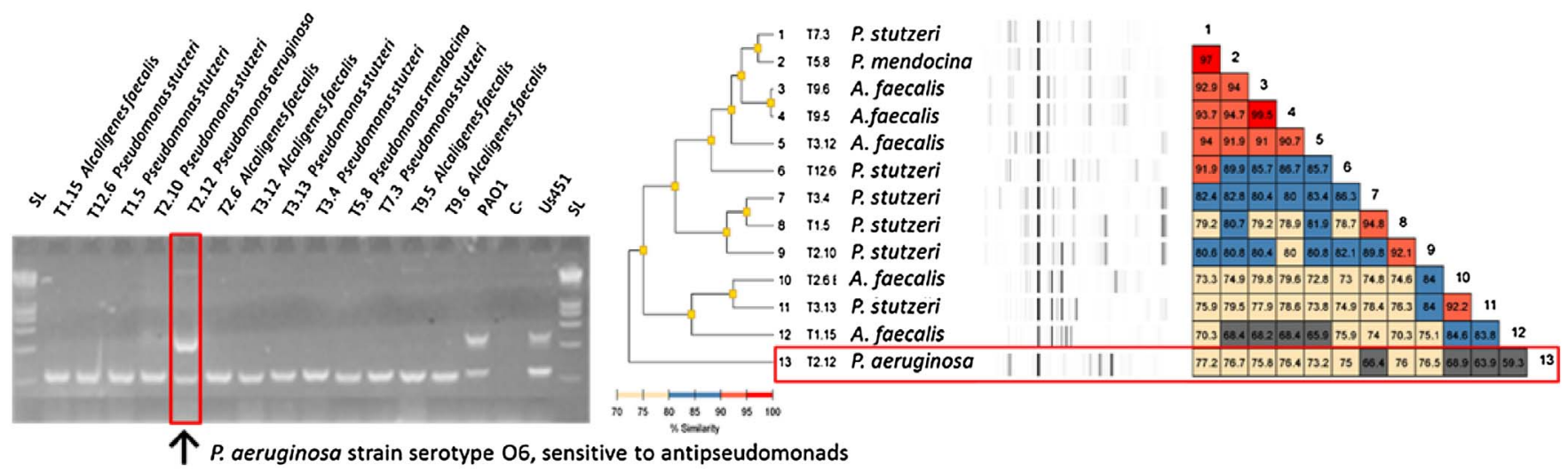

Fig. 1. DNA fingerprinting by Rep-PCR (Diversilab, BioMérieux) of the 13 pseudomonads strains obtained from oral and cloacal swabs of free-living turtles of Príncipe Island.

Pseudomonas-related infections in turtles has been described, especially in pet, farm and zoo turtles, being responsible for shell necrosis, abscess formation, osteomyelitis (Adkesson et al., 2007), pneumonia (Óros et al., 2005), dermatitis (Ladyman et al., 1998; Óros et al., 2005) and conjunctivitis (Di Ianni et al., 2015). Although sea turtles are not considered a relevant source of resistant zoonotic strains, problems may arise due to the increase of eco-tourism and consumption of turtle-derived products, including meat and eggs (Aguirre et al., 2006; Magnino et al., 2009; Warwick et al., 2013).

This work represents a first approach to evaluate the presence of antibiotic resistant pseudomonads in wild free-living sea turtles from Príncipe Island, São Tomé and Príncipe, Gulf of Guinea. Such studies are essential, allowing the establishment of rational environment management and nature conservation programs.

\section{Materials and methods}

Oral and cloacal AMIES swabs (VWR, Leuven, Belgique) of freeliving turtles (Eretmochemys imbricata, $\mathrm{n}=10$ and Chelonia mydas, $\mathrm{n}=2$ ) were collected in 2010 from animals free of gross signs of disease, in the nearshore waters of Príncipe Island (Gulf of Guinea), during "Programa SADA" (Sustainable Conservation of the Hawksbill Breeding Population at the Príncipe Island, https://tartarugasstomeprincipe. wordpress.com/programa-sada/). Oral and cloacal swab was already described by Dickinson et al. (2001) as a good non-traumatic technique for the characterization of tortoise microbiota and for the assessment of populations' health status. Also, Oliveira et al. (2010) demonstrated that similar collection and transport procedures allow for the isolation of Gram-negative bacteria, even if involving long distances and processing periods.

Sample collected from oral or cloacal were run separately. After sampling, turtles were released back to the sea and swab samples were immediately placed in an icebox, and kept refrigerated until transporting to the Microbiology and Immunology Laboratory from the Veterinary Faculty in Lisbon, Portugal, where were further processed.

Aerobic bacteria isolation from swabs was performed on Columbia agar supplemented with 5\% sheep blood (COS, BioMérieux, Marcyl'Etoile, France), and Pseudomonas Selective Agar (CFC, Oxoid, Erembodegem, Belgium), both incubated at $37^{\circ} \mathrm{C}$ for $24-48 \mathrm{~h}$. Isolates were characterized through their macro and microscopic morphology, Gram staining characteristics and oxidase reaction. All Gram-negative, oxidase positive bacilli $(n=87)$ were selected for further characterization.

Pseudomonads screening was performed by multiplex-PCR (oprI/ $o p r L$ ), using primers and conditions previously described (De Vos et al., 1997). The oprI-positive isolates $(n=13)$ were then identified biochemically at species level using the Vitek 2 system (BioMerieux, Marcy-l'Etoile, France), and antibiotic resistance (ABR) profiling was performed using the same system in accordance with the manufacturer's instructions. Antibiotic compounds were tested as previously (Serrano et al., 2017) and were as follows: amikacin, aztreonam, cefepime, ceftazidime, ciprofloxacin, colistin, gentamicin, imipenem, meropenem, piperacillin + tazobactam, ticarcillin, ticarcillin + clavulanic acid, and tobramycin. Antibiotic resistance phenotypes, represented by the minimum inhibitory concentrations (MICs) were interpreted according to CLSI guidelines for Bacteria Isolated from Animals (CLSI, 2015a). The breakpoints of aztreonam, cefepime, ceftazidime, ciprofloxacin, colistin, meropenem, piperacillin + tazobactam, and tobramycin, not defined at the above CLSI, were interpreted according to CLSI (2015b). P. aeruginosa ATCC 27853 was included as control strain.

Additionally, all Pseudomonas isolates were genotyped by repetitive extragenic palindromic-polymerase chain reaction (REP-PCR) using the DiversiLabTM system, software version 3.4, (BioMerieux, Brussels, Belgium), while the $P$. aeruginosa isolate was also serotyped (Pirnay et al., 2009).

\section{Results}

From the 87 oxidase positive isolates obtained, 13 were classified as pseudomonads, based on the presence of oprI (14.9\%). One of these isolates was also oprL-positive, being identified as Pseudomonas aeruginosa. According to their biochemical profile, isolates were identified as follows: Pseudomonas aeruginosa $(\mathrm{n}=1)$, Pseudomonas mendocina $(\mathrm{n}=1)$, Pseudomonas stutzeri $(\mathrm{n}=6)$ and Alcaligenes faecalis $(\mathrm{n}=5)$.

Regarding strains susceptibility profile, five (total of 38.5\%) were susceptible to all antibiotics tested: four $P$. sutzeri and one $P$. aeruginosa (Table 1). Concerning antibiotic resistance (ABR) profile two strains were resistant to ticarcillin, ticarcillin + clavulanic acid, and aztreonam, two were resistant to ticarcillin and aztreonam and four were resistant only to aztreonam. No multidrug resistant (MDR) strains were detected, since none was non-susceptible to at least three antibiotic agents belonging to different categories (Magiorakos et al., 2012).

Genotypic DNA fingerprinting did not show any specific clonalcluster similarity (Fig. 1). The only $P$. aeruginosa strain identified had a susceptible drug profile and was serotyped as 06.

\section{Discussion and conclusion}

Sea turtles have been described as potential reservoirs for pathogenic and antibiotic resistant bacteria (Al-Bahry et al., 2009; Warwick et al., 2013), including pseudomonads, which screening is extremely relevant, since they may cause severe infections in these endangered species (Óros et al., 2005 Adkesson et al., 2007; Di Ianni et al., 2015; Ladyman et al., 1998). Therefore, evaluating the presence of antibiotic resistant pseudomonads in wild free-living sea turtles from Príncipe Island is extremely relevant, as this country comprises important areas for turtles' feeding and nesting (Formia et al., 2003). In fact, if 
conditions are favorable, these opportunistic bacteria may out-grow the turtles' microbiota and be responsible for increased morbidity and disease dissemination in those wild animal populations (Dickinson et al., 2001), while also contributing for increased environmental shedding (Barbour et al., 2007). They may also have a negative impact on these endangered species reproduction success, as already observed by Stenkat et al. (2014) regarding free-living birds.

Although the percentage of pseudomonads obtained in this study is not high (14.9\% - only 13 isolates were classified as pseudomonads between 87 oxidase positive isolates obtained), it should not be neglected. We are aware that it would be desirable to include more samples in this study, but considering the logistics required for sample collection it was not be possible to do so. Isolates were taxonomically allotted to $P$. aeruginosa, $P$. stutzeri, $P$. mendocina, and A. faecalis. A. faecalis are environmental microorganisms that can also be found in the human fecal microbiota, being rarely responsible for human diseases (Chu and Harkness, 2016). Although they can present several resistant traits that can eventually disseminate through the environment to other animals and humans (Zurek and Nayduch, 2016), they were not considered relevant for this study, as are not associated with disease in turtles. Moreover, in De Vos et al. (1997) Alcaligenes genus did not tested positive for oprI, contrary to our study. As biochemical identification tests are optimized for human isolates, further molecular studies will be needed to confirm A. faecalis identification.

Regarding Pseudomonas spp., several species have been already related with disease in turtles (Adkesson et al., 2007; Al-Bahry et al., 2009; Barbour et al., 2007; Díaz et al., 2006; Di Ianni et al., 2015; Foti et al., 2009; Ladyman et al., 1998; Óros et al., 2005) and zoonotic transmission, being associated with several human diseases including otitis, dermatitis, urinary and respiratory infections, especially among cystic fibrosis patients, meningitis, endocarditis and bacteremia (Warwick et al., 2013). The $P$. aeruginosa isolate detected was from serotype 06 , a predominant serotype commonly obtained from samples from several origins, including cystic fibrosis patients, human and animal diseases and the environment (Pirnay et al. 2002, 2009). This isolate was included in another study (Serrano et al., 2017) in which it was concluded that animal $P$. aeruginosa population is homogeneously scattered and indistinguishable from the global population structure.

The major concern regarding Pseudomonas species is their antibiotic resistance (ABR) ability, as they are intrinsically resistant to several antibiotic classes, but are also able to express acquired resistance traits due to mutations targeting chromosomal genes, efflux pumps, peptidoglycan-recycling genes, porins, topoisomerases and lipopolysaccharides, or due to acquisition of horizontally transferred resistance genes (Oliver et al., 2015). It is also important to refer that these resistant traits can be horizontally transferred to other bacterial species through mobile genetic elements, easily exchanged among phylogenetically distant bacteria, representing an extra concern (Al-Bahry et al., 2009; Farias et al., 2015).

The antibiotic crisis is increasing worldwide (Oliver et al., 2015), including in marine environments, where resistant bacteria can be considered an index of aquatic pollution (Foti et al., 2009). The presence of resistant strains in free-living endangered species of sea turtles is of special concern, due to the probability of transmission to humans, especially local populations, tourists and ecologists working in conservation projects, and other wildlife animals (Barbour et al., 2007).

The fact that none of the Pseudomonas strains in this study (and all the $A$. faecalis strains) was considered MDR was expected. The resistance to one or two antibiotic classes observed in eight strains must probably result from intrinsic antibiotic resistance ability of $P$. aeruginos $a$ and its capacity to express acquired resistance mechanisms (Oliver et al., 2015).

Both sea turtles, E. imbricata and C. mydas, have extensive migratory routes (Camacho et al., 2013; González-Garza et al., 2015; MonzónArgüello et al., 2011; Orós et al., 2005; Whiting et al., 2008), increasing the probability of contacting with waste products including antibiotic residues, oil spills, heavy metals and pesticides (Al-Bahry et al., 2012; Warwick et al., 2013), which can select for resistant strains (Farias et al., 2015; Foti et al., 2009). Regarding their feeding habits, both species are omnivorous, although preferring sponges and algae (Shuyler et al., 2013; Warwick et al., 2013), which can accumulate chemicals and toxic wastes. Debris ingestion has also been described (Shuyler et al., 2013; Warwick et al., 2013). Also, these turtles can contact other animals that are known reservoirs of resistant bacteria, including pelagic fish (Al-Bahry et al., 2009), wild birds (Stenkat et al., 2014), and sea mammals (Fertl and Fulling, 2007). Therefore, antibiotic resistance can be commonly found in several natural habitats, not necessarily being related with anthropogenic antibiotic administration and application (Farias et al., 2015). Although the presence of ABR Pseudomonas in turtles and tortoises was already described by several studies (AlBahry et al. 2009, 2012; Barbour et al., 2007; Foti et al., 2009), we did not confirm the presence of MDR pseudomonad strains in this region.

DiversiLab is an efficient method to detect subtle genomic differences when applied to very closely related strains, being more useful for short term studies and outbreaks investigation (Maatallah et al., 2013), whereas sequencing and Multilocus sequence typing (MLST) are more useful for long term epidemiological studies (Spratt, 1999). Although we did not perform sequencing, DiversiLab system results allow concluding that there was none specific clonal-cluster similarity (Fig. 1).

In conclusion, periodical evaluation of the presence of antibioticresistant bacteria in endangered turtles can contribute to the success of environmental management programs as previously suggested (AlBahry et al., 2009; Barbour et al., 2007). Although MDR strains were not found in wild free-living sea turtles in Príncipe Island, a continuous monitoring of $A B R$ in free-living wild animals should be considered as a tool to help us understand ABR-spread and incidence and find strategies to deal with this worldwide problem. Even in remote locations MDRbacteria can be found which may represent a risk, especially for the local human populations, considering the limited health assistance and therapeutic options. The whole turtle environment, including migration routes, feeding and nesting areas, should be considered as a potential source and scrutinized in conservation programs.

\section{Acknowledgements}

Sample collection at the Gulf of Guinea was conducted under the Programa SADA coordinated by Universidade do Algarve, Portugal and funded by Oceanário de Lisboa, Portugal, and by a Marine Turtle Conservation Act - U.S. Fish \& Wildlife Service grant. Laboratory work was supported by the Interdisciplinary Research Centre for Animal Health, Faculty of Veterinary Medicine, University of Lisbon (FMV/UL) (Project UID/CVT/00276/2013) and by the Laboratory of Molecular and Cellular Technology, Queen Astrid Military Hospital, Brussels, Belgium.

\section{References}

Adkesson, M.J., Travis, E.K., Weber, M.A., Kirby, J.P., Junge, R.E., 2007. Vacuum-assisted closure for treatment of a deep shell abscess and osteomyelitis in a tortoise. JAVMA 231, 1249-1254.

Aguirre, A.A., Gardner, S.C., Marsh, J.C., Delgado, S.G., Limpus, C.J., Nichols, W.J., 2006. Hazards associated with the consumption of sea turtle meat and eggs: a review for health care workers and the general public. EcoHealth 3, 141-153.

Al-Bahry, S., Mahmoud, I., Elshafie, A., Al-Harthy, A., Al-Ghafri, S., Al-Amri, I., Alkindi, A., 2009. Bacterial flora and antibiotic resistance from eggs of green turtles Chelonia mydas: an indication of polluted effluents. Mar. Pollut. Bull. 58, 720-725.

Al-Bahry, S.N., Al-Zadjali, M.A., Mahmoud, I.Y., Elshafie, A.E., 2012. Biomonitoring marine habitats in reference to antibiotic resistant bacteria and ampicillin resistance determinants from oviductal fluid of the nesting green sea turtle Chelonia myda. Chemosphere 87, 1308-1315.

Barbour, E.K., Chacra, N.A., Gali-Mouhtaseb, H., Jaber, L., Nehme, P., Shaib, H., Sadek, R., Usayran, N., 2007. Performance, bacterial shedding and microbial drug resistance in two tortoise species. Vet. Rec. 161, 62-64.

CLSI, 2015a. Performance Standards for Antimicrobial Disk and Dilution Susceptibility Tests for Bacteria Isolated from Animals. CLSI Supplement VET01S, 3rd ed. Clinical and Laboratory Standards Institute, Wayne, PA. 
CLSI, 2015b. Performance Standards for Antimicrobial Susceptibility Testing. CLSI Supplement M100-S25. Clinical and Laboratory Standards Institute, Wayne, PA. Camacho, M., Luzardo, O.P., Boada, L.D., Jurado, L.F.L., Medina, M., Zumbado, M., Óros, J., 2013. Potential adverse health effects of persistente organic pollutants on sea turtles: evidences from a cross-sectional study on Cape Verde loggerhead sea turtles. Sci. Total Environ. 458-460, 283-289.

Chu, A.S., Harkness, J., 2016. Alcaligenes faecalis cellulitis after a dog bite: case report and literature review. Pediatr. Emerg. Care 16, 1-4.

Díaz, M.A., Cooper, R.K., Cloeckaert, A., Siebeling, R.J., 2006. Plasmid-mediated highlevel gentamicin resistance among enteric bacteria isolated from pet turtles in Louisiana. Appl. Environ. Microbiol. 72, 306-312.

De Vos, D., Lim Jr., A., Pirnay, J.P., Struelens, M., Vandenvelde, C., Duinslaeger, L., Vanderkelen, A., Cornelis, P., 1997. Direct detection and identification of Pseudomonas aeruginosa in clinical samples such as skin biopsy specimens and expectorations by multiplex PCR based on two outer membrane lipoprotein genes, oprI and oprL. J. Clin. Microbiol. 35, 1295-1299.

Di Ianni, F., Dodi, P.L., Cabassi, C.S., Pelizzone, I., Sala, A., Cavirani, S., Parmigiani, E., Quintavalla, F., Taddei, S., 2015. Conjunctival flora of clinically normal and diseased turtles and tortoises. BMC Vet. Res. 11, 91.

Dickinson, V.M., Duck, T., Schwalbe, C.R., Jarchow, J.L., Trueblood, M.H., 2001. Nasal and cloacal bacteria in free-ranging desert tortoises from the western United States. J. Wildl. Dis. 37, 252-257.

Farias, P., Espirito Santo, C., Branco, R., Francisco, R., Santos, S., Hansen, L., Sorensen, S., Morais, P.V., 2015. Natural hot spots for gain of multiple resistances: arsenic and antibiotic resistances in heterotrophic, aerobic bacteria from marine hydrothermal vent fields. Appl. Environ. Microbiol. 81, 2534-2543.

Fertl, D., Fulling, G.L., 2007. Interactions between bottlenose dolphins and sea turtles in Golfo Dulce, Costa Rica. Mar. Turt. Newsl. 115, 4-8.

Formia, A., Tiwari, M., Fretey, J., Billes, A., 2003. Sea turtle conservation along the Atlantic coast of Africa. Mar. Turt. Newsl. 100, 33-37.

Foti, M., Giacopello, C., Bottari, T., Fisichella, V., Rinaldo, D., Mammina, C., 2009. Antibiotic resistance of Gram negatives isolates from loggerhead sea turtles (Caretta caretta) in the central Mediterranean Sea. Mar. Pollut. Bull. 58, 1363-1366.

González-Garza, B.I., Stow, A., Sánchez-Teyer, L.F., Zapata-Pérez, O., 2015. Genetic variation, multiple paternity, and measures of reproductive success in the critically endangered hawsbill turtle (Eretmochelys imbricata). Ecol. Evol. 5, 5758-5769.

Haenni, M., Hocquet, D., Ponsin, C., Cholley, P., Guyeux, C., Madec, J.Y., Bertrand, X., 2015. Population structure and antimicrobial susceptibility of Pseudomonas aerugi nosa from animal infections in France. BMC Vet. Res. 11, 9.

Kümmerer, K., Henninger, A., 2003. Promoting resistance by the emission of antibiotics from hospitals and households into effluent. Clin. Microbiol. Infect. 9, 1203-1214.

Kümmerer, K., 2004. Resistance in the environment. J. Antimicrob. Chemother. 54, 311-320.

Ladyman, J.M., Kuchling, G., Burford, D., Boardman, W., Raidal, S.R., 1998. Skin disease affecting the conservation of the western swap tortoise (Pseudemydura umbrina). Aust. Vet. J. 76, 743-745.

Maatallah, M., Bakhrouf, A., Habeeb, M.A., Turlej-Rogacka, A., Iversen, A., Pourcel, C., Sioud, O., Giske, C.G., 2013. Four genotyping schemes for phylogenetic analysis of Pseudomonas aeruginosa: comparison of their congruence with multi-locus sequence typing. PLoS One 8, e82069.
Magiorakos, A.P., Srinivasan, A., Carey, R.B., Carmeli, Y., Falagas, M.E., Giske, C.G., Harbarth, S., Hindler, J.F., Kahlmeter, G., Olsson-Liljequist, B., Paterson, D.L., Rice, L.B., Stelling, J., Struelens, M.J., Vatopoulos, A., Weber, J.T., Monnet, D.L., 2012. Multidrug-resistant, extensively drug-resistant and pandrug-resistant bacteria: an international expert proposal for interim standard definitions for acquired resistance. Clin. Microbiol. Infect. 18, 268-281.

Magnino, S., Colin, P., Dei-Cas, E., Madsen, M., McLauchlin, J., Nockler, K., Maradona, M.P., Tsigarida, E., Vanopdenbosch, E., Van Peteghem, C., 2009. Biological risks associated with consumption of reptile products. Int. J. Food Microbiol. 134, $163-175$.

McCarthy, K., 2015. Pseudomonas aeruginosa: evolution of antimicrobial resistance and implications for therapy. Sem. Respir. Crit. Care Med. 36, 44-55.

Monzón-Argüello, C., Loureiro, N.S., Delgado, C., Marco, A., Lopes, J.M., Gomes, M.G., Abreu-Grobois, F.A., 2011. Príncipe island hawksbills: genetic isolation of an eastern Atlantic stock. J. Exp. Mar. Biol. Ecol. 407, 345-354.

Oliveira, M., Monteiro, J.L., Rana, S., Vilela, C.L., 2010. Antimicrobial resistance profile of gram positive bacteria isolated from skin of healthy timorese river buffalo (Bubalus bubalis). Trop. Anim. Health Prod. 42, 833-839.

Oliver, A., Mulet, X., López-Causapé, C., Juan, C., 2015. The increasing threat of Pseudomonas aeruginosa high-risk clones. Drug Resist. Updates 21-22, 41-59.

Óros, J., Torrent, A., Calabuig, P., Déniz, S., 2005. Diseases and causes of mortality among sea turtles stranded in the Canary Islands, Spain (1998-2001). Dis. Aquat. Org. 63, $13-24$.

Pirnay, J.P., De Vos, D., Cochez, C., Bilocq, F., Vanderkelen, A., Zizi, M., Ghysels, B., Cornelis, P., 2002. Pseudomonas aeruginosa displays an epidemic population structure. Environ. Microbiol. 4, 898-911.

Pirnay, J.P., Matthijs, S., Colak, H., Chablain, P., Bilocq, F., Van Eldere, J., De Vos, D., Zizi, M., Triest, L., Cornelis, P., 2005. Global Pseudomonas aeruginosa biodiversity as reflected in a Belgian river. Environ. Microbiol. 7, 969-980.

Pirnay, J.P., Bilocq, F., Pot, B., Cornelis, P., Zizi, M., Van Eldere, J., Deschaght, P., Vaneechoutte, M., Jennes, S., Pitt, T., De Vos, D., 2009. Pseudomonas aeruginosa population structure revisited. PLoS One 4, e7740.

Serrano, I., Oliveira, M., Santos, J.P., Bilocq, F., Leitao, A., Tavares, L., Pirnay, J.P., De Vos, D., 2017. Antimicrobial resistance and genomic rep-PCR fingerprints of Pseudomonas aeruginosa strains from animals on the background of the global population structure. BMC Vet. Res. 13, 58.

Shuyler, Q., Herdesty, B.D., Wilcox, C., Townsend, K., 2013. Global analysis of anthropogenic debris ingestion by sea turtles. Conserv. Biol. 28, 129-139.

Spratt, B.G., 1999. Multilocus sequence typing: molecular typing of bacterial pathogens in an era of rapid DNA sequencing and the internet. Curr. Opin. Microbiol. 2, 312-316.

Stenkat, J., Krautwald-Junghanns, M.-E., Ornés, A.S., Eilers, A., Schmidt, V., 2014. Aerobic cloacal and pharyngeal bacterial flora in six species of free-living birds. J. Appl. Microbiol. 117, 1564-1571.

Warwick, C., Arena, P.C., Steedman, C., 2013. Health implications associated with exposure to farmed and wild sea turtles. J. R. Soc. Med. Short Rep. 4, 8.

Whiting, S.D., Murray, W., Macrae, I., Thorn, R., Chongkin, M., Koch, A.U., 2008. Nonmigratory breeding by isolated green sea turtles (Chelonia mydas) in the Indian Ocean: biological and conservation implications. Naturwissenschaften 95, 355-360.

Zurek, K., Nayduch, D., 2016. Bacterial associations across house fly life history: evidence for transstadial carriage from managed manure. J. Insect Sci. 16, 1-4. 